\title{
THE VIOLENCE OF INFLATED POSSIBILITIES: EDUCATION, TRANSFORMATION, AND DIMINISHMENT IN WAMENA, PAPUA
}

\section{Jenny Munro}

\section{Introduction}

"Eman, get ready for school! Where's Eman?? Eman, have you bathed yet?" called out Eman's older brother, Laurence. ${ }^{1}$

A forlorn-looking Eman appeared outside my hut, holding a garden spade that towered over his petite ten-year-old frame.

“Do I have to go to school? I'm helping with the garden," Eman implored.

“Nayak [Dani language, 'friend,' greeting used between males], you have to go to school. If you don't go to school we'll marry you off. Do you want to get married? You better get your pigs ready so you can get married," teased Laurence. (Fieldnotes, Wamena, June 20, 2006)

\footnotetext{
${ }^{1}$ All names in the article are pseudonyms chosen by informants. I am grateful to Dani informants who shared their experiences and allowed me to write about their lives. I thank David Webster, Danilyn Rutherford, and Lynette Parker for comments on earlier drafts of this article and Indonesia's editorial team for comments during the review process. Any remaining errors are, however, my own.
} 
Rather than bathe in the icy, turbulent We River and go to school on an empty stomach, children like Eman may become enthusiastic about doing hard labor in the family's subsistence garden. Getting children to school is a daily struggle for Baliem Valley Dani women (and some men), who protest the effort of organizing boisterous children when there is other work to do, when the expense of school fees, supplies, and uniforms is far more than they can bear, and when the prospect of facing the Indonesian school bureaucracy looms large. As much as mothers and others grumble about having to scrub a white uniform clean once again or being obliged to sit at the market all day selling garden produce to earn enough money, they also say, simply, "My child must go to school." (Lina, Wouma mother of four). ${ }^{2}$ Despite what children like Eman may desire, parents pursue education with vigor, and this endeavor commands much more investment than the time it takes to clean a school uniform or to earn money for school supplies.

To understand the urgency with which Dani highlanders pursue formal education, we may look to the cultural and political significance of educational achievement and literacy in other New Guinea societies. ${ }^{3}$ Lamont Lindstrom, among others, has argued that, in New Guinea societies, knowledge is power, especially for men competing for leadership positions in relatively egalitarian societies. ${ }^{4} \mathrm{New}$ skills in literacy may result in prestige or prowess because of education's association with foreign, Christian, and/or state power, its utility in local contests over status, and its power to grant material benefits for self and others. ${ }^{5}$ Eamonn McKeown argues that in Papua New Guinea, "the uses of reading and writing ... are strongly associated with local notions of self-promotion, prestige, chance, economic relations, and decoration." ${ }^{6}$

However, across the border from Papua New Guinea, in the highlands of Papua, ${ }^{7}$ Indonesia, indigenous men and women interpret, and experience, the value of

\footnotetext{
${ }^{2}$ Lina, June 22, 2006, Wamena, Papua.

${ }^{3}$ Papua is located on the western half of the island of New Guinea. The Dani share cultural commonalities with other New Guinea highlanders, including patrilineal, clan-based social units, a competitive "big man" political system comprising former war leaders who achieve status based on the production and distribution of wealth (traditionally, women and pigs), and intensive horticulture with an emphasis on pigs and sweet potatoes. See Anton Ploeg, "Huge Men in the Highlands of Irian Jaya," in Work in Progress: Essays in New Guinea Highlands Ethnography in Honour of Paula Brown Glick, ed. H. Levine and A. Ploeg (Frankfurt: Peter Lane Publishers, 1996), pp. 213-32.

${ }^{4}$ Lamont Lindstrom, "Doctor, Lawyer, Wise Man, Priest: Big-Men and Knowledge in Melanesia," Man 19,2 (1984): 291-309.

${ }^{5}$ Don Kulick and Christopher Stroud, "Christianity, Cargo and Ideas of Self: Patterns of Literacy in a Papua New Guinean Village," Man New Series 25,2 (1990): 286-304; M. Meggit, "Uses of Literacy in New Guinea and Melanesia," Bijdragen tot de Taal-, Land- en Volkenkunde 123,1 (1967): 73-74.

${ }^{6}$ Eamonn McKeown, "Modernity, Prestige, and Self-Promotion: Literacy in a Papua New Guinea Community," Anthropology and Education Quarterly 37,4 (2006): 367. See also Eamonn McKeown, "Biros, Books and Big-Men: Literacy and the Transformation of Leadership in Simbu, Papua New Guinea," Oceania 72 (2001):105-16.

${ }^{7}$ Since 2003, Papua has been divided into two provinces, Papua and West Papua. I use "Papua" to mean both provinces in line with the indigenous concept of Tanah Papua, or Land of Papua, and to reflect cultural, historical, and political continuities that have not changed with the introduction of the new West Papua province. Internationally, and among indigenous activists, it is common to refer to Papua as West Papua.
} 
education in relation to political conditions they view as ongoing colonialism. ${ }^{8}$ Papuan independence movements, which predate Indonesian rule, continue to draw attention to political and economic inequality, and human rights violations, and to dispute Indonesia's takeover of the region in $1969 .{ }^{9}$ In many areas of Papua, Indonesian settlers and migrants outnumber Papuans, and practices that enable Indonesian settlers and migrants to maintain economic and social dominance continue in spite of the adoption of decentralization policies that are said to empower indigenous Papuans. ${ }^{10}$

In this article, I examine the experiences of educated Dani men and women trying to gain access to the promising power of literacy in Wamena, the main city in the central highlands of Papua. I draw on an ethnographic study of the educational journeys of Dani university students conducted in North Sulawesi and Papua in 200506, and on materials obtained during supplementary visits to Wamena in 2009, 2011, and $2012 .^{11}$

Although the meaning of education is certainly mediated by local sociocultural norms, experiences of achievement, prestige, prowess, and confidence described elsewhere in New Guinea highlands cultural contexts are much more limited for educated Dani men and women in Papua than for Indonesians and migrants. In examining why this might be the case, I draw attention to what Joel Robbins calls "diminishment" —discourses of race, wildness, childishness, backwardness, primitiveness, and temporal "behindness" at play in colonial situations that can cause humiliation and a sense of inferiority. ${ }^{12}$ My understanding of diminishment draws on current scholarly conversations about human experience and subjectivity, "including the ways in which inner processes are reshaped amidst economic and political reforms, violence, and social suffering." ${ }^{13}$ Diminishment may produce "social suffering," or

\footnotetext{
${ }^{8}$ For example, S. Eben Kirksey, Freedom in Entangled Worlds: West Papua and the Architecture of Global Power (Durham, NC: Duke University Press, 2012); John Braithwaite, Valerie Braithwaite, Michael Cookson, and Leah Dunn, Anomie and Violence: Non-truth and Reconciliation in Indonesian Peacebuilding (Canberra:

Australian National University E-Press, 2010); Jacques Bertrand, Nationalism and Ethnic Conflict in Indonesia (Cambridge: Cambridge University Press, 2004).

${ }^{9}$ George Aditjondro, Cahaya Bintang Kejora: Papua Barat dalam Kajian Sejarah, Budaya, Ekonomi dan Hak Asasi Manusia (Jakarta: Elsham, 2000); Benny Giay, "Against Indonesia: West Papuan Strategies of Resistance against Indonesian Political and Cultural Aggression in the 1980s," in Violence in Indonesia, ed. Ingrid Wessel and Georgia Wimhöfer (Hamburg: Abera, 2001), pp. 129-38; John Saltford, The United Nations and the Indonesian Takeover of Papua, 1962-1989: The Anatomy of Betrayal (London: Routledge, 2003).

${ }^{10}$ Rodd McGibbon, "Plural Society in Peril: Migration, Economic Change, and the Papua Conflict," Policy Studies 13 (Washington, DC: East-West Center, 2004); Richard Chauvel, "Constructing Papuan Nationalism: History, Ethnicity, and Adaptation," Policy Studies 14 (Washington, DC: East-West Center, 2005); Muridan S. Widjojo, Adriana Elisabeth, Amiruddin, Cahyo Pamungkas, and Rosita Dewi, Papua Road Map: Negotiating the Past, Improving the Present and Securing the Future (Jakarta: Indonesian Institute of Sciences, 2008).

${ }^{11}$ The initial fieldwork project was approved by the Human Research Ethics Committee of the Australian National University. The visit to Wamena in 2012 was supported by a Canadian Institutes of Health Research IGH Gender, Sex and Health Trainee KT Supplement and received approval from the University of Calgary Conjoint Health Research Ethics Board.

${ }^{12}$ Joel Robbins, "Humiliation and Transformation: Marshall Sahlins and the Study of Cultural Change in Melanesia," in The Making of Global and Local Modernities in Melanesia: Humiliation, Transformation, and the Nature of Cultural Change, ed. Joel Robbins and Holly Wardlow (Aldershot: Ashgate, 2005), p. 11.

${ }^{13}$ João Biehl, Byron Good, and Arthur Kleinman, "Introduction: Rethinking Subjectivity," in Subjectivity: Ethnographic Investigations, ed. João Biehl, Byron Good, and Arthur Kleinman (Berkeley and Los Angeles, CA: University of California Press, 2007), p. 1.
} 
cause damage to a person's sense of dignity and worth when the field of possibilities before him or her is heavily circumscribed by structural conditions. ${ }^{14}$ Diminishment, I argue, is a practice of Indonesian rule that shapes Dani experiences of literacy and educational achievement. ${ }^{15}$

Diminishment is coupled with nation-state and local discourses that inflate the transformative potential of education. When Indonesian authorities emphasize what educational achievement may deliver for aspiring participants on the frontier of the Indonesian nation-state, they deceptively elide conditions that limit the success of indigenous men and women. In particular, the state's agenda of educating and "civilizing" has contributed to the marginalization of indigenous people by enhancing the power of Indonesian settlers and migrants. Dani understandings reflect, and exceed, the state's promises regarding education, but the quality of schooling in their area is arguably the worst in Indonesia. Indigenous participation in schooling is further challenged by political violence and injurious social forces. As university students and graduates lead indigenous political resistance, becoming educated may also result in experiences of political violence and state reprisals. As for the results of educational attainment, statistical data indicate the ongoing exclusion of indigenous people from employment by practices that favor Indonesian migrants. Ethnographic illustrations show that Dani attempts to make use of their educational status in encounters with Indonesians and/or the government system may be cut short in disappointing, humiliating, and frustrating ways. The inflated possibilities of education may be considered a form of violence because these claims set indigenous men and women up to fail amid unacknowledged conditions that make personal, social, and political transformation a highly improbable outcome of schooling in highlands Papua.

\section{Education, Diminishment, and Promises of Transformation}

In Indonesia, education is widely regarded as an equalizer and an important path to prosperity, authority, respect, and social mobility. ${ }^{16}$ Urban lifestyles commonly epitomize the attainment of modernity or "progress" (kemajuan, in Indonesian, which may also be translated as "getting ahead" or "going forward"). Education also promises to deliver power and justice to populations and territories:

For life in the future, regions [in Indonesia] that possess superior quality human resources will be in control and will be able to make use of the momentum of empowerment that is deterministic for the prosperity of an area ... Just look at our neighbouring countries ... with high-quality human resources they are able to create prosperity and justice for their nations. ${ }^{17}$

\footnotetext{
${ }^{14}$ Iain Wilkinson, "Social Suffering and the New Politics of Sentimentality," in Routledge International Handbook of Contemporary Social and Political Theory, ed. Gerard Delanty and Stephen P. Turner (Oxon and New York, NY: Routledge, 2011), p. 463. See also Veena Das, Arthur Kleinman, Mamphela Ramphele, and Pamela Reynolds, eds., Violence and Subjectivity (Berkeley, CA: University of California Press, 2000).

${ }^{15}$ Joel Robbins, "Humiliation and Transformation," p. 11.

${ }^{16}$ Pam Nilan, Lynette Parker, Linda Bennett, and Kathryn Robinson, "Indonesian Youth Looking towards the Future," Journal of Youth Studies 14,6 (2011): 709-28. Pam Nilan, "Youth Transitions to Urban, Middleclass Marriage in Indonesia: Faith, Family, and Finances," Journal of Youth Studies 11,1 (2008): 65-82.

17 "Infleksibilitas Otonomi Pendidikan," Kompas, August 10, 2001.
} 
In Papua, schooling serves as a powerful advertising medium for national cultural messages about the transformative, modernizing, and equalizing potential of education. ${ }^{18}$ In 1963, Indonesia was allowed to take control of Papua under the condition that a plebiscite be held to determine the wishes of Papuans within six years. In preparation for the "Act of Free Choice" referendum in 1969, Indonesia's military presence in Papua grew exponentially, and the indigenous inhabitants experienced great brutality and oppression. ${ }^{19}$ Yet violence has not been the only strategy taken up by the Indonesian state to promote order and assimilation in Papua. Regarding state promotions of national-cultural belonging in Biak, an island off the north coast of Papua, Danilyn Rutherford writes, "School children learned through such representations that Indonesia's regions were separate but culturally equivalent." ${ }^{20}$ Through participating in the national education system, young people may identify with relatively standardized national values, and thereby acquire a sense of belonging and cultural inclusion in the Indonesian nation. ${ }^{21}$ Former President Megawati Sukarnoputri famously remarked, "Kindergarten is a decisive factor in the formation of Indonesian national character." ${ }^{22}$

In Papua, promises about the power of education to create modernity, development, equality, and inclusion take shape in relation to potent forms of diminishment that identify inadequacies allegedly possessed by the indigenous inhabitants. ${ }^{23}$ Reflecting widespread popular understandings of Papuan capabilities, an Indonesian journalist comments,

There is not a landing, mountain range, valley, river, or sea in Papua that does not provide a potential life for its occupants. So why are many people poor, left behind, backward, naked, and ignorant? ${ }^{24}$

\footnotetext{
${ }^{18}$ Lynette Parker, From Subjects to Citizens: Balinese Villagers in the Indonesian Nation-State (Copenhagen: NIAS, and London: Taylor \& Francis, 2003).

${ }^{19}$ Larry L. Naylor, "Culture Change in the Balim Valley, Irian Jaya, Indonesia" (PhD dissertation, Southern Illinois University at Carbondale, 1974), p. 13; and Theo Van den Broek and Alexandra Szalay, "Raising the Morning Star: Six Months in the Developing Independence Movement in West Papua," Journal of Pacific History 36,1 (2001): 78.

${ }^{20}$ Danilyn Rutherford, Raiding the Land of the Foreigners: The Limits of the Nation on an Indonesian Frontier (Princeton, NJ: Princeton University Press, 2003), p. 208.

${ }^{21}$ Parker, From Subjects to Citizens; see also Saya Shiraishi, Young Heroes: The Indonesian Family in Politics (Ithaca, NY: Cornell Southeast Asia Program Publications, 1997); R. Rosaldo, "The Borders of Belonging Nation and Citizen in the Hinterlands," in Cultural Citizenship in Island Southeast Asia: Nation and Belonging in the Hinterlands, ed. R. Rosaldo (Berkeley and Los Angeles, CA: University of California Press, 2003), pp. $1-15$.

22 "Taman Kanak-kanak Tentukan Pembentukan Karakter Bangsa," Kompas, July 3, 2001.

${ }^{23}$ For more on colonial/racial constructions of indigenous inadequacies, see, for example, Danilyn Rutherford, Laughing at Leviathan: Sovereignty and Audience in West Papua (Chicago, IL: University of Chicago Press, 2012); Chris Ballard, "Oceanic Negroes': British Anthropology of Papuans, 1820-1869," in Foreign Bodies: Oceania and the Science of Race 1750-1940, ed. Bronwen Douglas and C. Ballard (Canberra: Australian National University E-Press, 2008), pp. 157-201; Richard Chauvel, "West New Guinea: Perceptions and Policies, Ethnicity and the Nation State," in Australia in Asia: Episodes, vol. 3, ed. Anthony Milner and Mary Quilty (Melbourne: Oxford University Press, 1998), pp. 191-204; Lloyd Rhys, Jungle Pimpernel: The Story of a District Officer in Central Netherlands New Guinea (London: Hodder and Stoughton, 1947).

24 "Terpuruk di Tanah Leluhur," Kompas, February 23, 2003.
} 
Indonesian perceptions of Papuans are often condescending and directly contribute to Papuan experiences of diminishment. An Indonesian scholar refers to Papuan students as having "limited cognitive learning capacity and creativity." ${ }^{25}$ Educators have proposed to put Papuan children and youth into dormitories to isolate them from their parents and so-called negative cultural and social influences so that they may become good students. ${ }^{26}$ These characterizations reflect the ongoing significance of what David Webster calls the Papua bodoh (stupid Papuan) ideology as a feature of Indonesian rule. $^{27}$

In Wamena, in the central highlands of Papua, education is supposed to facilitate development and usher in an era of complete transformation. Beginning in the 1950s, missionaries brought "a new organization with new rules and social expectations," sometimes using forceful techniques to impose these changes on local residents. ${ }^{28}$ Funded by the Dutch colonial government, these schools were intended to bring "a whole new conditioning and change in basic psychological attitudes." 29

After Indonesia gained political control of Papua, the education system proposed to rapidly modernize Dani lifestyles to prepare them for inclusion in the nation-state, by violent means if necessary. ${ }^{30}$ The occupiers' prevailing perception of the Dani was that they were "a living Neolithic community" whose members would have to abandon their traditions and learn everything from foreign teachers. ${ }^{31}$ As Indonesian soldiers were deployed to carry out educational activities in Dani territory in the 1970s, it was made clear to the indigenous residents that transformation as Indonesian authorities would implement it contained both violence and promises of a better future. Education vowed "to prepare an indigenous workforce ... to become implementers of ... development projects," ${ }^{32}$ because, supposedly, "[i]n the central

\footnotetext{
${ }^{25}$ Roosmalawati Rusman, "Youth, Education, and Employment in Irian Jaya," Perspectives on the Bird's Head of Irian Jaya, Indonesia: Proceedings of the Conference, Leiden, 13-17 October 1997, ed. Jelle Miedema, Cecilia Ode, and Rien A. C. Dam (Amsterdam: Rodopi, 1998), p. 378.

${ }^{26}$ Ibid.

${ }^{27}$ David Webster, "'Already Sovereign as a People': A Foundational Moment in West Papuan Nationalism," Pacific Affairs 74,4 (2001-2002): 507-28; and David Webster, "Race, Identity, and Diplomacy in the Papua Decolonization Struggle, 1949-1962," Race, Ethnicity, and the Cold War: A Global Perspective, ed. Philip E. Muehlenbeck (Nashville, TN: Vanderbilt University Press, 2012), pp. 91-117. Indonesian scholars also offer critical perspectives on ruling ideologies and conditions in Papua. See for example, Aditjondro, Cahaya Bintang Kejora, and Widjojo et al., Papua Road Map.

${ }^{28}$ Charles Farhadian, "Comparing Conversions among the Dani of Irian Jaya," in The Anthropology of Religious Conversion, ed. Andrew Buckser and Stephen D. Glazier (Lanham, MD: Rowman and Littlefield, 2003), p. 64.

${ }^{29}$ Denise O'Brien, "Economic and Social Development," in Working Papers in Dani Ethnology, ed. Leopold J. Pospisil (United Nations Temporary Executive Authority in West New Guinea-West Irian, Bureau of Native Affairs, 1962), p. 82.

${ }^{30}$ Naylor, "Culture Change." See also Richard Chauvel and Ikrar N. Bhakti, "The Papua Conflict: Jakarta's Perceptions and Policies," Policy Studies 5 (Washington, DC: East-West Center), p. 5; Dale Gietzelt, "The Indonesianization of West Papua," Oceania 59,3 (1989): 201-21; Jaap Timmer, Living with Intricate Futures: Order and Confusion in Imyan Worlds, Irian Jaya, Indonesia (Nijmegen: Centre for Pacific Studies, 2000).

${ }^{31}$ Robert Gardner and Karl Heider, Gardens of War: Life and Death in the New Guinea Stone Age (London: Deutsch, 1968), p. 42.

${ }^{32}$ R. M. Koentjaraningrat, ed., Membangun Masyarakat Majemuk, Irian Jaya (Jakarta: Djambatan), p. 458.
} 
highlands, there are no traditional skills and abilities ... that can be used as a basis for development... ${ }^{33}$

Those who advocate educating Papuans suggest it will help them compete with Indonesians, or even prevent migrants from coming to Papua and dominating its economy and government in the first place. Suko Bandiyono concludes that Indonesian migrants are more "modern" than indigenous Papuans in social, economic, demographic, and physical aspects. ${ }^{34}$ Therefore,

Non-migrants need to accelerate their self-adjustment in the process of modernization so they are not left behind. If they are incapable of eliminating their left-behindness [ketertinggalan] then they will be increasingly marginalized in the city. ${ }^{35}$

Even while promoting education as a way of minimizing marginalization by Indonesian migrants, experts hold out little hope that Papuans can ever compete with Indonesians because of innate inadequacies allegedly demonstrated by Papuans. For example, Roosmalawati Rusman commented during a 1997 conference in Leiden, "Compared to migrants, indigenous youth have no spirit of entrepreneurship. They are used to living in an environment that spoils them."

As Chris Ballard, S. Eben Kirksey, and others have noted, representations of primitiveness in Papua are longstanding, and always serve a political agenda. ${ }^{37}$ Indonesian authorities present educational achievement as a way of enabling indigenous highlanders to compete with Indonesian migrants for jobs and status, but the need to educate or transform the Dani justifies the increasing presence, and power, of Indonesians. Reflecting on Dani participation in schooling in the 1970s, Soeharini Soepangat recommends that the Dani be exposed to "more examples of modern men," or Indonesian migrants, to bring to life values of modernity that she feels are only partially and awkwardly being cultivated in schools. ${ }^{38}$ As if based on recommendations such as these, throughout the 1990 s and 2000 s, migrants were provided with positions of power as professionals, entrepreneurs, administrators, and schoolteachers. During these decades, it was true that no indigenous person held a position of power over a migrant in Wamena. The practice of diminishment, particularly the claim of indigenous primitiveness and the corresponding need for education to transform Dani men and women, directly enables Indonesian dominance in the highlands.

\footnotetext{
${ }^{33}$ Ibid., p. 461.

${ }^{34}$ Suko Bandiyono, Penyesuaian Diri Migran di Daerah Perkotaan Irian Jaya (Jakarta: Puslitbank Kemasyarakatan dan Kebudayaan Lembaga Ilmu Pengetahuan Indonesia, 1996), p. 80. For similar arguments, see Parsudi Suparlan, "Kesukubangsaan dan Primordialitas: Program Ayam di Desa Mwapi, Timika, Irian Jaya," Antropologi Indonesia 54,21 (1997): 38-61; and Parsudi Suparlan, "Model Sosial Budaya bagi Penyelenggaraan Transmigrasi di Irian Jaya," Antropologi Indonesia 57,22 (1998): 23-47.

${ }^{35}$ Ibid., p. 80.

${ }^{36}$ Rusman, "Youth, Education, and Employment," p. 379.

${ }^{37}$ Chris Ballard, "West Papua," The Contemporary Pacific 14 (2002): 467-76; and S. Eben Kirksey, "From Cannibal to Terrorist: State Violence, Indigenous Resistance and Representation in West Papua" (MPhil thesis, University of Oxford, 2002).

${ }^{36}$ Ibid., p. 321.
} 
The in-migration of Indonesians has important implications for Dani experiences of diminishment and the transformative potential of education. Stuart Upton argues that the movement of Indonesians to the region has limited the educational and employment opportunities of indigenous people to such an extent that this marginalization is a driving force behind Papuan identity, nationalism, and hostility towards newcomers, irrespective of the massive land grabs and violent practices perpetuated by the state towards indigenous Papuans. ${ }^{39}$ Today, Wamena is home to about thirty thousand Indonesian settlers and migrants, and an equal number of indigenous residents, mostly Dani and other central highlanders. Indonesian settleradministrators bring to life judgments that find the Dani to be inferior and deficient in relatively undisguised ways. ${ }^{40}$ These views disadvantage indigenous people in their interactions with those from other ethnic groups, especially in relation to employment. Circuitously, lower levels of employment reinforce migrants' perception of Papuans as backward. ${ }^{41}$

In these conditions, Dani men and women, like other Papuan highlanders, might find themselves wondering not just about the undelivered promises of educational achievement, or elusive experiences of equality and justice, but also to what extent they could actually possess the inadequacies they are alleged to represent. Writing of Korowai people in the southern highlands, Rupert Stasch describes "extreme parental enthusiasm and self-sacrifice in relation to children's education." ${ }^{42}$ Moreover,

The basis of its [education's] desirability is a version of the civilized/primitive hierarchy or the hierarchy of economic development and geopolitical capitalization, in the sense that in this area the Korowai are responding to a perception of themselves as occupying a disenfranchised position in an overarching hierarchy of human worth. ${ }^{43}$

Dani understandings of education are not only influenced by Indonesian practices of diminishment and promises of transformation, but reflect indigenous valuations of knowledge, leadership, prestige, and authority. Perhaps most of all, experiences of colonialism are a powerful force motivating the pursuit of formal education.

\footnotetext{
${ }^{39}$ Stuart Upton, "The Impact of Migration on the People of Papua, Indonesia: A Historical Demographic Analysis" (PhD dissertation, University of New South Wales, 2009), p. 4. See also Chris Manning and Michael Rumbiak, Economic Development, Migrant Labour, and Indigenous Welfare in Irian Jaya, 1970-84 (Canberra: National Centre for Development Studies, Research School of Pacific Studies, Australian National University, 1989).

${ }^{40}$ Gietzelt, "The Indonesianization of West Papua." See also Leslie Butt and Jenny Munro, "Rebel Girls? Unplanned Pregnancy and Colonialism in Highlands Papua, Indonesia," Culture, Health, and Sexuality: An International Journal for Research, Intervention and Care 9,6 (2007): 585-98.

${ }^{41}$ Upton, "The Impact of Migration," pp. 456-57.

${ }^{42}$ Rupert Stasch, "Figures of the Primitive in Papuan Self-Representations: Korowai Transformations of Tourist and State Evolutionist Ideologies," paper presented at the annual meeting of the American Anthropological Association, San Francisco, CA, November 18, 2012.

${ }^{43}$ Ibid.
} 


\section{Dani Understandings of Education}

To better understand the meanings Dani attach to education, it is helpful to consider the kinds of everyday statements people make about schooling. While I was conducting ethnographic research in Wamena, informants' statements suggested several themes: education as a way of personal advancement, particularly if education could result in tangible results and major transformations; education as a way of overcoming alleged backwardness, including the lack of knowledge and experience that enables Indonesian colonization; and education as a way of gaining access to knowledge and material benefits that could be used to resist Indonesian dominance and restore indigenous control of land and social life.

My informants described education as a way of gaining prestige, and suggested that an educated person would acquire skills and experiences that might lead to an increased ability to do good things for others. ${ }^{44}$ Siko, a university student I interviewed in North Sulawesi on his graduation day, proposed, "I am just a village boy born in the garden but I wanted to learn and now I have. I am going home to help the community." ${ }^{45}$ This comment, typical of the views of many students, partly reflects the broader cultural significance of helping others in a society in which "big man" leadership norms remain important. "Big men" may be defined as clan or community leaders who acquire status and influence in return for helping others achieve various social, political, and religious ends. ${ }^{46}$ Laura Zimmer-Tamakoshi writes, "The only way Big Men achieve and keep status is by raising the names of their groups as well as their own reputations and by making good things happen for others as well as for themselves and their children (or at the very least, making a good appearance of doing so). ${ }^{47}$ Doing good things for others might also translate into wide-reaching social, political, and economic change. Laurence, a university student originally from Wouma village, said, "We want to do everything, there is no electricity, people have no shoes, and everything is expensive because there is no road." ${ }^{48}$ Using education to help others was also described as an obligation. Lex, a student activist in his fourth year of political sciences in North Sulawesi, stated,

I want to finish quickly and try to become a civil servant because they are the only ones with a salary in Papua. My parents also want this. I am the only one from my village who is going to be a graduate so I feel responsible. All the people in the village want a graduate. ${ }^{49}$

Educated Dani whom I interviewed emphasized the need to produce tangible results and material benefits (hasil) for their families and community members in order

\footnotetext{
${ }^{44}$ Doug Hayward, "From Tribal Economics to a Market-Oriented Society," Irian: Bulletin of Irian Jaya Development 11,2-3 (1983): 10-11. See also Agus A. Alua, ed., Nilai-nilai Hidup Masyarakat Hubula di Lembah Bulim Papua (Jayapura: Sekolah Tinggi Teologi Fajar Timur, 2006).

${ }^{45}$ Siko, April 25, 2006, Tondano, North Sulawesi.

${ }^{46}$ Ibid., p. 108.

${ }^{47}$ Laura Zimmer-Tamakoshi, "The Last Big Man: Development and Men's Discontents in the Papua New Guinea Highlands," Oceania 68,2 (1997): 110.

${ }^{48}$ Laurence, November 19, 2005, Manado, North Sulawesi.

${ }^{49}$ Lex, December 6, 2005, Tondano, North Sulawesi.
} 
to fulfill their obligations in a gift economy. ${ }^{50}$ For example, Daud, an elementary school teacher and father of four children who was upgrading his education in North Sulawesi commented on the challenges of living up to community expectations.

There is so much support in Wamena if the kids [students] will just take the money and work hard, finish quickly. The kids have to learn well here, because over there it is all in the field. If you do not know what to do it will be obvious. The people will think there is no use in supporting students. ${ }^{51}$

Daud also described how people from his village, Manda, organized communal donation drives to collect money for young peoples' education. From Detta, a woman living in Wamena, I heard about the practice of selling tubers, sweet potatoes, and other garden produce to earn money to send to relatives away at university. ${ }^{52}$ Those on the receiving end of financial support suggested that education would not translate into prestige unless educated individuals could prove to others what they had learned by taking action and creating positive results for others. For example, Jally summarized, "If we get out into the field [turun lapangan] and do not know anything, the people are going to laugh at us. They will say, look at this guy, he has a degree [sudah sarjana], and he cannot do anything." 53

A desire to overcome stigmas of primitiveness and backwardness also motivated educational pursuits. Papua is usually described as having the poorest quality human resources (sumber daya manusia) in Indonesia. ${ }^{54}$ During my research, it was not uncommon for Dani men and women to agree that Papuans are lacking in education or are "backward," saying, for example, "People do not know anything," "They are left behind," or commenting that they are simply "low," in a reference to the quality of the human resources. ${ }^{55}$ Some university students and other educated people described their commitment to changing the "backward" beliefs and practices of other Dani. Minke, a female university student, said:

Because of all the new regencies coming down we have to fill up the positions. We have to provide a good example for others. Everyone in Papua is disappointed, regretful [menyesal]. The young ones do not want to go to school, they are unemployed, and they drink too much. We have to impress upon them that they cannot do this, and they must go to school. We have to modernize them [kasih maju]. They still wear the penis gourd [koteka], but people must go to school. We have to go forward [maju] in order to achieve independence [merdeka]. ${ }^{56}$

\footnotetext{
${ }^{50}$ In her book, Permissive Residents: West Papuan Refugees Living in Papua New Guinea (Canberra: Australian National University E-Press, 2008), Diana Glazebrook describes the importance of being able to produce results for Dani refugees in Papua New Guinea who are considering a return home to Papua.

${ }^{51}$ Daud, February 10, 2006, Tondano, North Sulawesi.

${ }^{52}$ Detta, June 17, 2006, Wamena, Papua.

${ }^{53}$ Jally, November 30, 2005, Tondano, North Sulawesi.

${ }^{54}$ Jenny Munro, “Dreams Made Small: Humiliation and Education in a Dani Modernity" (PhD dissertation, Australian National University, 2009); and Jenny Munro, "Taking on Development: Papuan Youth, HIV / AIDS and State Discourse in Eastern Indonesia," (MA thesis, University of Victoria, 2004).

55 Munro, "Dreams Made Small."

${ }^{56}$ Minke, February 1, 2006, Tondano, North Sulawesi.
} 
Even though they toyed with ideas of highlanders' supposed inadequacies, university students were also adamant that the Indonesian government is responsible for the low levels of education in Papua. Indonesia, as Hannah, a law student, explained, has employed a system of "ignorance education" (pendidikan pembodohan) to keep indigenous people powerless. ${ }^{57}$

Informants also argued that education was important in order to overcome colonialism, suggesting that Indonesia had been able to "cheat" the Dani and take over their lands because they "did not know things." ${ }^{58}$ Elders indicated that the ability to read and write, gain employment, enter into settler-dominated institutions of governance and enterprise, and challenge colonial practices have all become matters of survival. For example, Wenabu, a Wouma gardener and grandfather with no formal education, said,

It is good if children go to school because we work hard in the garden, but we still do not have anything. Why can other people do it but we can't? Everywhere we go now we run into pendatang [lit. newcomers, meaning Indonesian settlers and migrants], they have taken our land in the city ... We still have a war to fight with Indonesia. ${ }^{59}$

Kisogo, who had briefly attended a Dutch-run school in the 1950s and was recognized as a "big man" in his community, described how educated Dani could bring order to cultural systems and land rights that had disintegrated under Indonesian rule.

We used to have all of these families, Lago-Matuan, Hubi-Kossy, and so forth, and we used to control this land ... We had everything organized. Now, under this government system, we do not know what to do ... We just hope the younger generation will become educated and they will figure out these problems ... 60

The views of Dani informants suggest that they would like to use literacy and education to "bridge the social chasm" ${ }^{61}$ of colonial relations and to promote themselves in ways that could translate into increased authority and the all-important ability to do good things for others. These understandings of education point to schooling as a way of gaining ground under conditions marked by the chaos and injustice that have been produced by colonialism; the aspirants hope to gain ground by building confidence and achieving educational status that is highly respected in both Dani and Indonesian terms. Indigenous perspectives also indicate that transformation is, in fact, the hoped-for outcome of educational attainment.

\footnotetext{
${ }^{57}$ Hannah, September 13, 2006, Manado, North Sulawesi. See Jenny Munro, "“ A Diploma and a Descendant!' Premarital Sexuality, Education, and Politics among Dani University Students in North Sulawesi, Indonesia," Journal of Youth Studies 15,8 (2012): 1019. Other informants made similar statements, see Munro, “Dreams Made Small.”

58 Ibid.

${ }^{59}$ Wenabu, July 2, 2006, Wamena, Papua.

${ }^{60}$ Kisogo, June 19, 2009, Wamena, Papua.

${ }^{61}$ M. J. Meggit, "Uses of Literacy in New Guinea and Melanesia," Bijdragen tot de Taal-, Land- en Volkenkunde 123,1 (1967): 73.
} 
The remainder of this article explores why and how educated Dani women and men are limited in achieving the kind of results they hope for, and the sort of prestige and sense of prowess described elsewhere in New Guinea cultural contexts. I draw attention to the political conditions of Indonesian rule, and the potent influence of settlers and migrants in the daily lives of urban and rural Dani. Promises of transformation through education, however unlikely, gain most of their significance because of the violence, exclusion, and prejudice that characterizes Indonesian rule in Papua.

\section{So Where is the Education (and Employment)?}

A key feature of the politics of education in Papua is that inflated promises of transformation have been promulgated in a region hampered by the poorest quality and least accessible schooling in Indonesia. ${ }^{62}$ According to government statistics, Papua province has an illiteracy rate of 26 percent among citizens 15 through 44 years old, which is ten times the national Indonesian average, and these figures show a worsening trend between 2003 and $2010 .{ }^{63}$ Educational resources and services are concentrated in urban, coastal areas, with far lower levels of educational provision and attainment in the rural, highland areas. ${ }^{64}$ In Jayawijaya regency, where Wamena is located, the illiteracy rate hovers around 60 percent. ${ }^{65} \mathrm{~A}$ recent World Bank study found that in Jayawijaya there are just four primary schools per one thousand schoolage children, which is roughly half the national average ${ }^{66}$ Around 60 percent of all villages in Jayawijaya do not have a primary school, and the average distance from these villages to the nearest school is seven kilometers. The average distance from these villages to a secondary school ranged from twenty-three to thirty-two kilometers. ${ }^{67}$ Local terrain is hilly or mountainous, criss-crossed by rivers and a patchwork of marshes, swamps, and gardens. Transportation is limited and expensive. In addition to these problems of access to education, the quality of teaching is questionable given that teachers are absent during school hours approximately 30 percent of the time. ${ }^{68}$ Not surprisingly, given these constraints and other challenges, Jayawijaya has one of the lowest net school enrollment rates in Indonesia. ${ }^{69}$ At the same time, school enrollment is high among high-income residents of Jayawijaya, ${ }^{70}$ most of whom are Indonesian migrants. In other words, the education system appears

\footnotetext{
${ }^{62}$ Julius Ary Mollet, "Educational Investment in Conflict Areas of Indonesia: The Case of West Papua Province," International Education Joumal 8,2 (2007): 155-66. See also The World Bank, Investing in Indonesia's Education at the District Level: An Analysis of Regional Public Expenditure and Financial Management (Washington, DC: The World Bank, 2009).

${ }^{63}$ Badan Pusat Statistik Republik Indonesia/Susenas, "Percentage of Population Who are Illiterate by Province and Age Group, 2003-2010," available at: http:/ /dds.bps.go.id/eng/tab_sub/view.php?tabel= 1\&daftar=1\&id_subyek=28\&notab=5, accessed on February 21, 2012.

${ }^{64}$ Upton, "The Impact of Migration."

${ }^{65}$ The World Bank, Investing in Indonesia's Education, p. 41.

${ }^{66}$ Ibid., p. 36.

${ }^{67}$ Ibid., p. 42.

${ }^{68}$ Ibid., p. 39.

${ }^{69}$ Ibid., p. 42.

${ }^{70}$ Ibid.
} 
to have failed the indigenous population and to be creating serious inequalities between the indigenous and non-indigenous residents. ${ }^{71}$

The fact that high-quality education is unavailable for indigenous youth in highlands Papua is an important way that national and local discourses of transformation are removed from daily realities, and silent on conditions of exclusion and inequality. Rather than becoming a powerful way to overcome inequalities, the education system creates conditions in which indigenous youth are likely to experience failure. The apparent failure of indigenous men and women to capitalize on opportunities that were never really there to begin with is a critical manifestation of the practice of diminishment.

\section{The Possibilities of Education amidst Everyday Violence}

Conditions of violence and the everyday challenges of schooling, which, like education system inequities, are largely unacknowledged by those who assert the possibility of radical change, make education and employment less attainable. Young Dani adults aged twenty-five to thirty-five years of age constitute the first generation to be entirely schooled in the Indonesian system. They have also experienced a lifetime of political violence. Decentralization laws have increased the presence and reach of soldiers, police, paramilitary units, and mobile brigades in Papua, bringing the average per capita deployment of security forces, relative to citizens, to five times that of other areas of Indonesia. ${ }^{72}$ Young adults I interviewed recalled fleeing from Indonesian mobile brigade police (Brimob) during ethnic riots that broke out on October 6, 2000, after soldiers attacked participants in a separatist demonstration. ${ }^{73}$ Penggu, a university student, stated, "The conditions on the ground in Wamena are terrible; people are chased like animals by the military." ${ }^{74}$

Becoming educated may also enhance the risk of experiencing political violence perpetrated by the security sector. Papuan university students and graduates have taken leading roles in human rights activism and are highly critical of Indonesian rule, leading to reprisals such as detention, murder, torture, and imprisonment. ${ }^{75}$ Since I first conducted fieldwork in 2005, two of my university student informants, Eric Logo and Hubertus Mabel, have been killed by security-sector gunfire in Papua, while another, Dominikus Sorabut, is currently a political prisoner. Dani university students I have

\footnotetext{
${ }^{71}$ Upton, "The Impact of Migration," p. 443.

${ }^{72}$ Leslie Butt, "Young Female Sex Workers' Experiences of HIV / AIDS Testing and Treatment in Conditions of Political Violence in Highlands Papua, Indonesia," Western Humanities Review 66,3 (2012): 45.

${ }^{73}$ See Octavianus Mote and Danilyn Rutherford, "From Irian Jaya to Papua: The Limits of Primordialism in Indonesia's Troubled East," Indonesia 72 (2001): 115-40. While the incident in October 2000 was the first time that widespread violence occurred between migrants and indigenous inhabitants in Wamena, there continue to be regular occurrences of security-sector violence against indigenous people.

${ }^{74}$ Penggu, November 2, 2005, Tondano, North Sulawesi.

${ }^{75}$ For more, see Human Rights Watch, Indonesia: Free Papuan Activists, July 21, 2009, available at: http:/ / www.unhcr.org/ refworld/ docid/4a682411c.html,accessed March 10, 2013; International Center for Transitional Justice and ELSHAM Papua, The Past That Has Not Passed: Human Rights Violations in Papua Before and After Reformasi (New York: International Center for Transitional Justice, 2012) available at: http: / / ictj.org/sites/ default/ files/ICTJ-ELSHAM-Indonesia-Papua-2012-English.pdf, accessed March 10, 2013.
} 
met with in Papua, North Sulawesi, Bali, and Jakarta all describe being under surveillance by state intelligence agents and intimidated by local authorities, usually after a spate of political violence in Papua. ${ }^{76}$

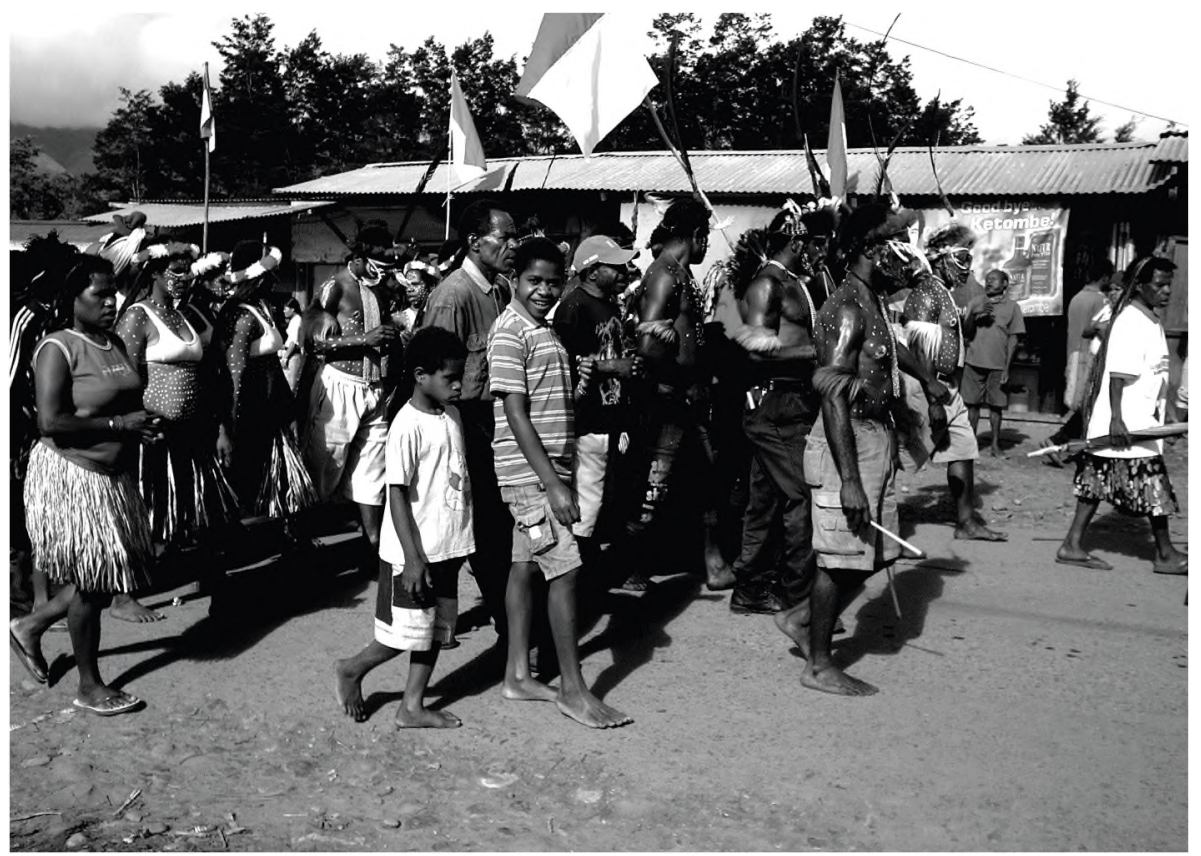

Figure 1: A Dani parade that occurred the day before President Yudhoyono visited Wamena

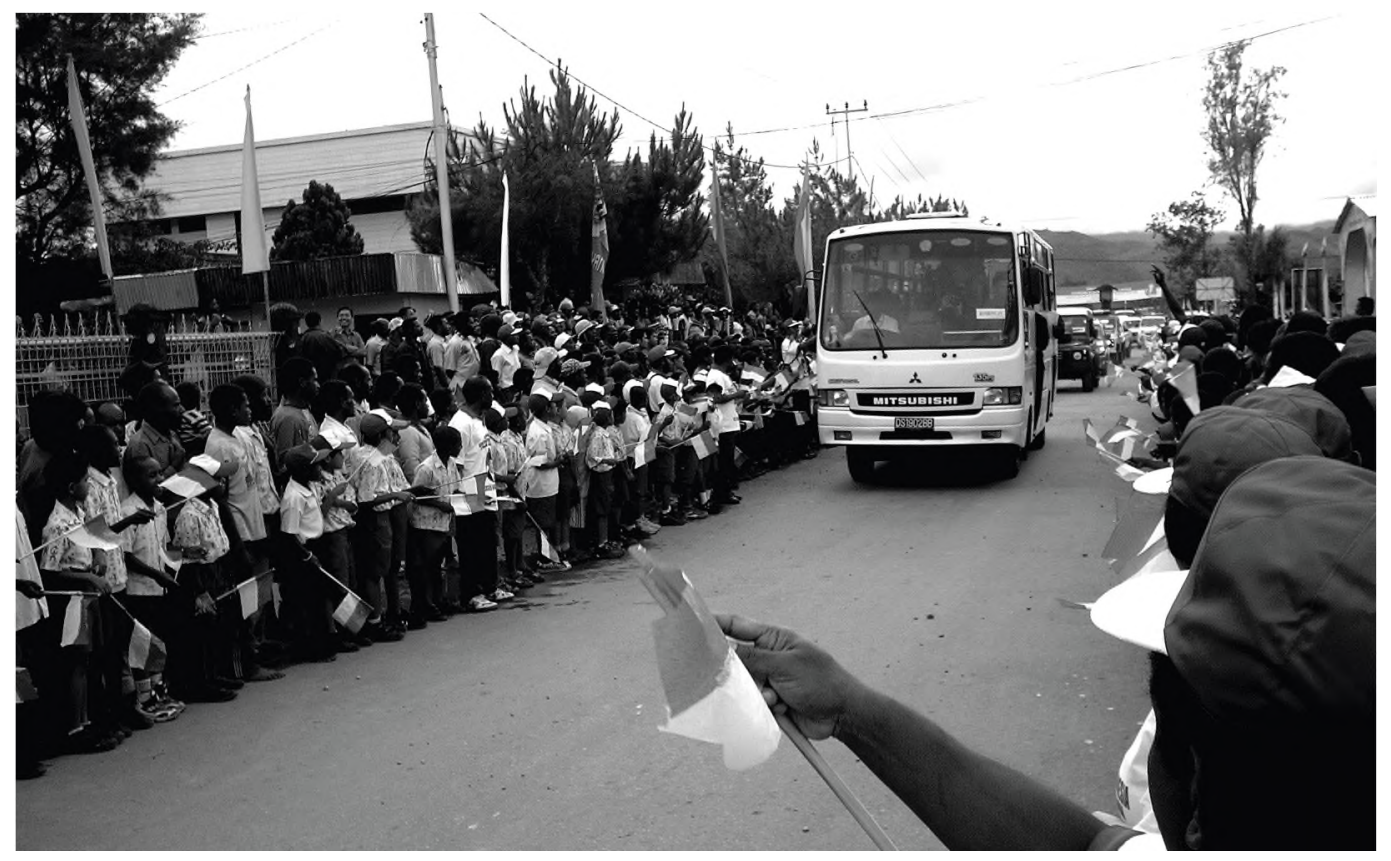

Figure 2: School children were assembled along city streets to wait for the president's arrival

${ }^{76}$ Munro, "Dreams Made Small," and “A Diploma and a Descendant," p. 1017. 
Violence and military intimidation limit opportunities for education and transformation for indigenous men and women, but Indonesian authorities insist that profound change is easily accessed by all. In July 2006, when Indonesian president Yudhoyono visited Wamena during the period when I was conducting research, soldiers occupied the front yards and gardens of indigenous homes in the city and on its rural fringes from dawn until dusk for over two weeks. When patrols approached women in the area where I was living, they fled, taking me with them, rather than speak to soldiers whom they feared would hurt them. Some residents chose to leave home for a few weeks rather than face soldiers on their property each day. Seeming bored and perhaps unaware of the impact of their army garb and weaponry, soldiers sought to make small talk with villagers and asked for cups of tea. Military patrols meandered through Dani neighborhoods, questioning inhabitants about their purpose for being on the street and demanding to see their identification cards. Authorities banned indigenous men and women from greeting the president or marking his visit with public displays of dancing and traditional attire. As a result, Dani marches took place in the days before his arrival (Figure 1, above). Only school children in uniform who neatly lined the city's streets were allowed to be seen by the president (Figure 2, above). Against the backdrop of these strict and in some cases offensive procedures, in a speech made during his visit (Figure 3), the president emphasized the possibility of equality and transformation through education, even for Papuans:

All of Indonesia's children are the same, because of this Papua's children are also Indonesia's children and so they all need to study diligently ... so you can become intelligent people and useful people. All of Indonesia's children have the same chance to achieve success, including children of Papua $\ldots{ }^{77}$

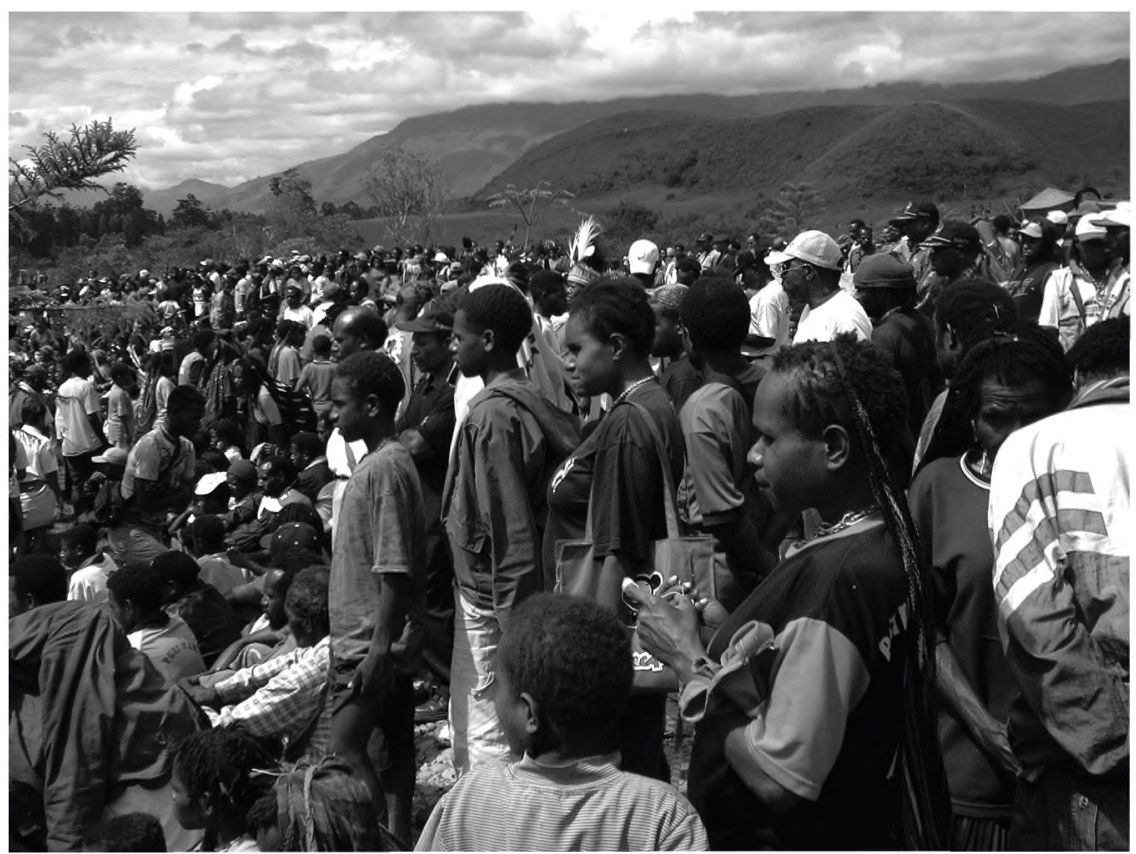

Figure 3: Indigenous attendees listening to the president's speech in Wamena

${ }^{77}$ Quoted in Cenderawasih Pos, July 28, 2006. 
The rhetoric of possibility, however patronizing, starkly contrasts with the actual conditions and educational opportunities available, judging from the challenges identified by young Dani. They suffered from lack of money for registration, uniforms, and bribes for teachers. Petrus, a young man entering junior high school, described the stress he was experiencing because his Indonesian elementary school teacher would not give him his diploma until he paid the man either a pig or 500,000 rupiah (about $\$ 50$ USD). ${ }^{78}$ Mina, a young mother, explained that she did not know her child's exact date of birth, and had no birth certificate, problems that deterred her from trying to register her daughter in school for fear she would be ridiculed by the teacher and school administrators. ${ }^{79}$ Teachers, books, and electricity were often missing in schools. Teaching styles were repeatedly described as causing fear or shame. Many youths moved to dormitories in Wamena from rural locales for junior and senior high school. Their descriptions of Papuan and Indonesian men who came to the dorms seeking out young indigenous women for sex with the knowledge of the $I b u$ Kos, or "Homestay Mother," are suggestive of the kind of troubling environment these students experienced. ${ }^{80}$ Young men and women described themselves as fortunate if they found themselves incorporated into an urban Dani or Indonesian household as a domestic laborer so they were able to live near school.

Participating in the education system is clearly a challenge because many young people are not in school at all. Those who drop out of school often get married, or try to earn money through menial jobs like washing the sport utility vehicles of Indonesians (vehicle ownership among Dani is rare), digging rocks out of the We River to sell to construction bosses, helping Indonesian taxi drivers get passengers, or, probably the most common, for young men, pedaling a becak (bicycle-taxi) around town from dawn until dusk. Wamena is the only place in Indonesia where gluesniffing is the drug of choice among youth, and, despite over a decade of interventions to assist these mostly homeless youths, the "glue kids" (anak aibon) only seem to grow in number. Papuans are experiencing a generalized epidemic of HIV.$^{81}$ Joram Yogobi, the director of Yukemdi, an HIV outreach organization in Wamena, has suggested that one in five indigenous street youths are testing positive for HIV. ${ }^{82}$ In these conditions, everyday realities affirm that education offers not only a means to transform one's life, but a way of escaping violence and hardship. That difficult living conditions motivate a vigorous pursuit of education but render educational goals unattainable is an illustration of how Dani youth experience the violence of inflated possibilities.

\section{Indigenous Employment}

Gaining employment in the public-service sector is an ideal outcome of education, and an outcome that could illustrate the transformative power of schooling, but Dani

\footnotetext{
${ }^{78}$ Petrus, December 27, 2011, Wamena, Papua.

${ }^{79}$ Mina, January 4, 2012, Wamena, Papua.

${ }^{80}$ Patrice, June 30, 2012, Wamena, Papua; Nina, June 28, 2012, Wamena, Papua.

${ }^{81}$ Leslie Butt, "Local Biologies and HIV/AIDS in Highlands Papua, Indonesia," Culture, Medicine, and Psychiatry 37(2013): 179-94.

${ }^{82}$ Joram, June 29, 2012, Wamena, Papua.
} 
men and women face serious challenges in achieving this outcome. Papuans have often been excluded or removed from employment, a practice that dates back to the previous Dutch colonial state. ${ }^{83}$ In the present day, Dani men and women are gaining employment in public service, a small number of notable individuals have achieved positions of prominence outside public service, and educated indigenous people are being elected as local government representatives with increasing frequency. At the same time, Indonesian laborers continue to be brought into Wamena to work on construction projects, and professional and entrepreneurial roles are dominated by Indonesians.

A recent round of government hiring indicates ongoing bias against indigenous people seeking work in the civil service, even those with a university education. Local indigenous people accounted for 112 of 275 new recruits (41 percent) in the June 2009 selection, while 163 of the new employees (59 percent) were from outside the central highlands. ${ }^{84}$ Following the common practice throughout Indonesia, local candidates should have an advantage over non-locals, but from the list of names it appears that approximately 60 percent of new recruits are not indigenous locals. Similar patterns prevail in other contexts. ${ }^{85}$ It is particularly significant that indigenous people are marginalized in government employment because public service is the main source of indigenous employment; indigenous people are rarely employed in private, commercial, or service sectors.

When we analyze government surveys and newspaper reports, it becomes clear that education is not transforming the lives of indigenous highlanders by qualifying them for jobs or earning them increased authority in relation to Indonesians. Given the presence of so many Indonesian settlers and migrants, who clearly hold an advantage in the competition for jobs, educated indigenous men and women may experience exclusion through "face work" interactions with Indonesians. Frederick Rawski writes,

People evaluate claims to authority by the ways in which those claims diverge or correspond with their own historical experience ... Indeed, it is only through the "face work" practices of local culture and politics that developmentalist and nationalist rhetoric become meaningful. ${ }^{86}$

The significance of education becomes most clear in moments of encounter, where "face work" brings to life "developmentalist and nationalist rhetoric," such as the notion of indigenous inadequacy.

\footnotetext{
${ }^{83}$ Van den Broek and Szalay, "Raising the Morning Star," p. 77.

${ }^{84}$ Working with Dani assistants, I analyzed the family names of the new employees accepted into Jayawijaya regency government to classify them as "local indigenous" and "non-indigenous." "Local indigenous" refers to employees whose family name identifies them as belonging to one of the three main indigenous groups of the central highlands-Dani, Yali, or Lani. "Non-indigenous" refers to all other new employees, both other Papuans and Indonesians.

${ }^{85}$ In Mamberambo Raya, a newly established regency immediately to the north of Jayawijaya, just three of 264 new recruits were from the central highlands, despite the fact that the regency capital is not far from Wamena and number of Dani reported they were encouraged to apply for jobs there.

${ }^{86}$ Frederick Rawski, "Jargon in the Jungle: Indonesian State Rhetoric at a Highland Sulawesi 'Access Point,"" Review of Indonesian and Malaysian Affairs 33,1 (1999): 185.
} 


\section{Hasil (Results) among Educated Dani}

The personal experiences of educated Dani men and women provide an ethnographic illustration of diminishment, exclusion, and the outcomes of educational attainment that builds on the evidence provided by statistical indicators. They show that Dani-Indonesian encounters frequently evoke expressions of inadequacy rather than prowess, even for educated Dani who have arguably achieved symbols of modern identity and status that Indonesia has articulated through its political presence.

\section{Mama Matius: A Daily Struggle to Get Ahead}

In 2006, Mama Matius (literally, Matius's mother) was about thirty-five years old. ${ }^{87}$ She was born and raised in Wouma on the fringes of Wamena city. She expressed pride at being one of two women from her village who graduated high school in the 1990s. Her husband, Frans, was also a high school graduate. He had acquired a government job at the local library after almost a decade of vying for a position. Their threebedroom house in town was a patchwork of wooden and woven panels that did little to keep out the chilly nighttime temperatures and was literally falling down around them. Mama Matius cooked meals over a fire outside the house next to a pig pen that was empty during many of my visits. Birds, mice, and puppies had taken over the pantry where she stored cooking implements, plates, and rice. The home had no electricity, and their two children struggled to do their homework by candlelight. A host of impoverished relatives migrated through their house, staying for a night or a month. Despite the monthly ration of rice that Frans received as part of his government salary, they were deeply in debt, especially to Indonesians who owned the small shops (kios) nearby where for years the family had purchased rice, cooking oil, instant noodles, sugar, and salt on credit.

Getting ahead (kemajuan) was a daily focus for Mama Matius. In a typical day, she left home at dawn to do chores at her uncle's house, because he, too, had financed the family's expenses, and then she went to her garden in the village. Midday, she stopped by home to drop off tubers for dinner or money for rice and vegetables, then left again for a community meeting, study group, or church-related activity in the afternoon. She returned home to boil water for tea and roast sweet potatoes at around 8:00 PM. Mama Matius sent her children to a Catholic elementary school that was more expensive, but that she argued was better quality than the local public schools. The school teacher was an Indonesian woman from North Sulawesi, with whom Mama Matius interacted on a daily basis when dropping off the children at school. She pointed out that the teacher's family was a good influence: "They are very modern, you know, the husband does not drink alcohol or smoke cigarettes, their clothes are clean and new, and they are never late for church."

Mama Matius had gone through the arduous process of taking the government employment examinations three times, but although she passed the tests, she had never been offered a job. She spoke of other plans-making handicrafts, selling betelnut, and getting a grant through one of the government "empowerment"

${ }^{87}$ Mama Matius was interviewed on a number of occasions when I was staying with her and her family in Wamena, including July 2006, June 2009, December 2011, and June 2012. 
(pemberdayaan) activities in which she often participated. Mama Matius expressed feelings of inadequacy and hopelessness at her inability to "go forward" (maju), saying, "We are educated but there are no results, we barely make enough money to eat and our house is falling apart. We are completely in debt with everyone so our salary goes right to our debt." She frequently reminded her son, Matius, "When you have done well in school, you can become an official [pejabat] and build Mama a good house."

In 2009, Mama Matius was suddenly offered a government job subject to payment of 15 million Indonesian rupiah, about US\$1,500, and equivalent to a two-year salary of a public servant in the highlands. Not quite believing this demand, Mama Matius described going to visit the regent ${ }^{88}$ (bupati) to verify the request in person:

I went to the regent's office after my friends started paying the money and getting their jobs. There were maybe twenty people waiting to see him for various reasons. The guards told us to sit on the floor outside his office. It was dirty, with garbage and cigarette butts strewn everywhere. I sat there most of the day. I was so hungry. Then an officer came out of the regent's office and started pointing to people, "You, you, you," he pointed around and told those men they could go in to meet the regent ... When I met the regent, I asked him if it was true that I had to pay 15 million rupiah to get an SK [surat keputusan, a letter stating the regent's decision to offer civil service employment]. He said yes. I told him I had worked as hard as I could, shoveling sand from the river for the past six months, and I had five million. I had borrowed two million, and I could not possibly get any more money. So he said okay, he would take my seven million and he would pay the remaining eight million so I could get an SK.

After paying the regent, Mama Matius worked for about a year sweeping the city streets and picking up garbage at dawn. Then, at age forty, about twenty years after graduating from high school, she was moved to a secretarial position at the local district office where she helped ration rice for the poor.

In this case, Mama Matius expressed shame at their living conditions, which she said ought to be better because Frans was employed and she was seeking economic opportunities every day. The Indonesian discourse of modernity (kemajuan) was very much present in her narrative and in her day-to-day activities. She measured herself against the achievements of her Indonesian neighbors, and articulated disappointment at her comparative failures, even though there was very little she could do to make her education translate into results. She tried many avenues and found herself hampered by corruption in the hiring system that favored applicants with access to large sums of money, but she was ultimately able to save enough money from her laborer job to pay off the regent. Her education made little difference in the regent's office, where she sat on the floor amid the garbage, waiting for a chance encounter. Frustration and disappointment characterized her experience as one of the first female high school graduates from her village.

\footnotetext{
${ }^{88}$ The regent was an indigenous man who, like other indigenous officials, was widely seen as representing the interests of the Indonesian state and migrants in Wamena. My informants overwhelmingly argued that the financial and political backing of Indonesians was necessary to get elected to the position of regent, and that since the first indigenous candidates were elected, they have implemented or supported the agendas of these allies.
} 
This example shows that becoming educated and literate provides just enough confidence, skills, and status to bring Dani women and men into close contact with Indonesians and the government system, where they may experience potent forms of diminishment and feelings of inadequacy. Becoming educated contributes to emotional investments in the promises and discourses of Indonesian modernity, but then the people who trusted the promises find themselves let down in ways that generate resentment as well as self-blame. The inflated promises of education-as-transformation bring women like Mama Matius into encounters where a sense of accomplishment is not forthcoming.

\section{Minimizing Embarrassment: Literacy among University Graduates}

Besides as a means to qualify for government employment, the major way that educated Dani men and women utilize literacy and formal education is by dealing with what Tania Li calls "power-saturated encounters" with the government bureaucracy and mostly Indonesian professionals, teachers, and civil servants, on behalf of other indigenous people. ${ }^{89}$ Among my informants, it was typical practice that if a visit to a government office, school, or hospital was unavoidable, rural or lesseducated individuals would be accompanied by an educated relative or friend to avoid the confusion, discomfort, and embarrassment that resulted from being treated badly by staff. For instance, Wenabu, an elder, described his encounters with civil servants as "humiliating" and "dizzying," in reference to the experience of having officials "talk in circles." He also described several attempts to bring important issues to the attention of civil servants on behalf of fellow villagers, attempts that ended in frustration and selfdoubt, for government officials would not let him in their offices to speak. ${ }^{90}$

In some cases, the efforts of educated individuals did translate into assistance to others. On the day school students received their report cards, mothers and fathers from Wouma village gathered at the home of Mama Matius to discuss who would have to go and collect the reports. Parents, mostly without formal education, said they were afraid they would be asked to sign their names, something they did not know how to do. Children were crying about the problem. Some university students were enlisted to visit three different elementary and junior secondary schools to collect reports on behalf of five children. One of the university students, Laurence, explained that,

Someone has told them they will have to sign their names, which is probably not true, but the fear of being embarrassed is too great ... at school, in offices, in front of others, they would appear strange. We cannot let them go through this, so we do it for them ... We do not feel so embarrassed because we have to do it, and we have more experience. ${ }^{91}$

\footnotetext{
${ }^{89}$ Tania Murray Li, "Masyarakat Adat, Difference, and the Limits of Recognition in Indonesia's Forest Zone," in Race, Nature, and the Politics of Difference, ed. Donald S. Moore, Jake Kosek, and Anand Pandian (Durham, NC: Duke University Press, 2003), p. 387.

${ }^{90}$ Wenabu, June 8, 2006, Wamena, Papua

${ }^{91}$ Laurence, July 2, 2009, Wamena, Papua
} 
In other cases, university-educated Dani were no more successful than other Dani in achieving results in their encounters with civil servants or professionals. In 2006, university students were able to enter the local Bureau of Statistics office to discuss an important community problem-the theft of government financial assistance fundsspeaking on behalf of the community. Shortly after being allowed into the office they were escorted back out the door. An Indonesian civil servant emerged to shout, "Disperse!" at a group of indigenous community members who had gathered to wait for the results of the meeting.

In these examples, university students and graduates may use literacy skills and experience with Indonesians to help others avoid humiliation or discrimination. Educated men and women may experience some sense of achievement in cultural terms, in such cases, because they are able to do good things for others. Yet the "go to" person who accompanies a neighbor on a visit to the doctor or types a letter does not achieve much prowess, prestige, influence, or social standing in the absence of tangible results and material benefits. Educated people often remain at the mercy of impoverished relatives for daily sustenance and lodging, until and unless they manage to acquire low-paying government jobs, often years after graduation. Thus, returning home from university, graduates like David expressed that, "everything is the same again." ${ }^{92}$ From the perspective of indigenous parents with no formal education, a little bit of literacy could help alleviate shameful encounters such as those they feared would take place at school on report card day. But for educated individuals, small acts of mediation do not produce the hoped-for benefits, tangible or intangible, that should result from many years at school or university.

Noteworthy in Laurence's explanation of how educated people may help uneducated relatives and friends is the lack of self-promotion or sense of high status. $\mathrm{He}$ is merely resigned to the fact that, "We have to do it ... We have more experience." In another place, perhaps such as Eamonn McKeown describes in Simbu, ${ }^{93}$ Papua New Guinea, educated youth might be advertising their literacy skills around town, emphasizing their accomplishments and how important they are in terms of helping community members. In Wamena, literacy just means more opportunities to encounter Indonesians and the government system in ways that produce disappointment, if not feelings of inadequacy, as a result of one's inability to make good things happen. Indonesian migrants and settlers "shape the myths of the state" ${ }^{94}$ for Dani men and women by affirming their relative powerlessness in these encounters.

\section{Conclusion: The Diminishment of Dani Achievements?}

Dani desires for education reflect Indonesian practices of diminishmentdiscourses of race, wildness, childishness, backwardness, primitiveness, and temporal "behindness" at play in colonial situations that can cause humiliation and a sense of

\footnotetext{
${ }^{92}$ David, July 4, 2009, Wamena, Papua

${ }^{93}$ McKeown, "Modernity, Prestige, and Self-Promotion."

${ }^{94}$ Joshua Barker and Gerry van Klinken, "Reflections on the State in Indonesia," in State of Authority: The State in Society in Indonesia, ed. Gerry van Klinken and Joshua Barker (Ithaca, NY: Cornell Southeast Asia Program Publications), p. 38.
} 
inferiority ${ }^{95}$-as well as the pursuit of aspirations that go beyond just becoming more sophisticated or less "backward." Looking at diminishment helps us understand why Dani parents may describe schooling with a sense of urgency, regardless of how poorly the expectation of well-fed children in pristine white uniforms, or university students requiring financial support in the millions of rupiah, meshes with their lived experiences of marginalization, poverty, and political violence. A keen sense of the political implications of knowledge, literacy, and employment, including the possibility of transforming existing inequalities, has also emerged out of experiences of being colonized. Yet the most obvious way that indigenous people can use literacy and formal education to achieve power-namely, through wage employment-is not easy, for their opportunities are restricted. Being educated may provide a degree of contingent currency for indigenous men and women interacting with Indonesian civil servants and other professionals. Educated Dani gain some social ground over uneducated Dani, but they still depend on their extended families for economic and social security, as well as sociability. While educated individuals end up acting as brokers or mediators to help others avoid embarrassing or humiliating encounters with Indonesians and others in power, these acts are really only significant because of conditions of extreme inequality dividing most of the indigenous residents from more privileged Indonesians. Rather than displaying a sense of their own prestige and prowess, many of the educated Dani men, women, and youth I encountered expressed resignation and referred to the mundane tasks they engage in that never come close to reflecting "results" (hasil), transformation, or personal prestige.

Educated Dani desire, and achieve, results that reflect political conditions in highlands Papua. Public and scholarly attention has been directed at state violence and human rights abuses in Papua, but the circumstances described in this article also point to more subtle forms of violence through which inner processes are reshaped. Indonesian discourses inflate the transformative powers of education, yet elide the realities of in-migration, poor-quality schooling, prejudicial hiring practices, and security-sector violence. In spite of the critical assessments of Dani men and women who have experienced these features of Indonesian modernity, these claims set indigenous men and women up to fail. The sense of being literate and educated provides Dani individuals with the confidence and experience to approach Indonesians, but face-to-face interactions and other close encounters frequently promote experiences of failure and disappointment. Failures in turn may appear to affirm the logic of diminishment. Practices of diminishment, coupled with political violence, limit what may result from educational attainment and simultaneously establish education as a sought-after route to power. But it is the violence of inflated possibilities and unlikely outcomes that may create more of the effects that university student Minke described, in which, "Everyone [in Papua] is disappointed and regretful." That a powerful sense of achievement is not the main experience educated Dani men and women identify as a result of their accomplishments suggests that a major cultural and political drama is unfolding in Papua that goes beyond questions of indigenous employment or the quality of schooling. Explicating the logic of this intersubjective drama calls for further investigation of the key emotional and affective constructs that underpin Indonesian rule and indigenous resistance in Papua.

${ }^{95}$ Robbins, "Humiliation and Transformation, " p. 11. 